\title{
Do gender and age of bank clients have an impact on bank card usage?
}

\author{
Ajtene Avdullahi ${ }^{1}$; Vjosa Fejza Ademi ${ }^{2 *}$ \\ 1) University of Mitrovica Isa Boletini, Kosovo \\ 2) University of Prishtina Hasan Prishtina, Kosovo
}

*To whom correspondence should be addressed. Email: vjosa.fejza@uni-pr.edu

\begin{tabular}{|l|l|l|l|l|}
\hline DOI: & Received: & Revised: & Accepted: & Published: \\
10.22437/ppd.v8i1.8839 & 09.03 .2020 & 23.03 .2020 & 25.03 .2020 & 30.04 .2020 \\
\hline
\end{tabular}

\begin{abstract}
This paper attempts to investigate the ownership and usability of debit and credit cards in Kosovo focusing on two demographic variables: the gender and age of the bank's clients. For research purposes, the Central Bank of Kosovo (CBK) data are used for two consecutive years: 2015 and 2016. The comparative method is used to compare the clients' behavior on the choice of the method to conduct payment and the usage of credit and debit cards in Kosovo banks for two consecutive years 2015 and 2016 based on the gender and age of bank clients. The results show that there is a gender gap, as debit and credit cards are owned and used more by males than females in all age groups and payment types. Whereas, for the variable age, the results show that both debit and credit cards are mostly used by customers aged 25-35 years followed by those 18-25 years. Based on the results of the paper, conclusions were drawn and some suggestions were given. We suggest that banks should do more to enhance the ownership and usage of debit and credit cards by females and elderly clients. Regarding the variable gender, we suggest that banks should offer credit and bonus cards with preferential rates to female entrepreneurs considering the very small number of female entrepreneurs to boost female entrepreneurship and decrease female unemployment in Kosovo.
\end{abstract}

Keywords: Card usage, Consumer Behavior, Female Entrepreneurship, Gender

JEL Classification: E42, G2, M31, M11, L26

\section{INTRODUCTION}

We live in a world full of choices. Some of our choices are important and some of them are insignificant. Choices are numerous and different that can be influenced by our behaviors as a consumer but also by the environment. As consumers, we buy products that are essential for everyday life but also other products for entertainment and luxury. One of the many decisions we face every day is the way we decide to pay for the services we receive and products purchased. Payment can be made in cash or noncash systems.

According to Mann (2007), the benefits of cash payments are obvious and are widely accepted. On the other hand, the advancement of information technology has influenced the transformation of payments from traditional payments in cash or through inside the bank services into sophisticated payments with bank cards and online 
payments. In addition to technological development, the Internet, Information systems, E-business and E-payments are becoming part of the everyday life of all people (Avdullahi, 2014).

Bank card technology has evolved rapidly from "classic" to contactless (Wang, 2008) and virtual cards, giving consumers better control over payments and increased transaction speed (Eyubolu \& Sevim, 2017). Nowadays, trading and payment methods have changed completely, offering a variety of payment methods. Financial institutions in today's economy have no longer the luxury to improve profit simply by increasing revenue (Avdullahi \& Fejza, 2015). Therefore, financial institutions have taken the path toward the digitalization of their products and services to cut operational costs and increase efficiency.

Numerous policies are practised for such services to be accepted by clients. Usually, Banks use incentives for their clients by offering lower prices for online services and by raising the prices of traditional inside the bank services. Although attractive incentives are offered still banks fail to completely transform the operating system because some clients prefer to pay higher costs for traditional services and payments. This question arises: Why some clients use one form or another of service or payment? When it comes to the services' sector, such as the banking sector, consumer behavior analysis becomes more complex and difficult to understand and analyze (Fejza, Bajrami, \& Livoreka, 2018). Services design in the banking sector, according to Chaker (2015) is very different from design in manufacturing, because services are intangible, warranty or repair processes are not as important as recovery or reimbursement processes.

Regarding card payment, the differences reflect respective social class values whereas members of the lower social classes tend to use their cards for instalment purposes; upper classes, for convenience (H. Lee \& John W, 1969). The bank cards are adopted differently depending on the type of economy of the respective country (Dospinescu, Anastasiei, \& Dospinescu, 2019).

Thus, scientific studies (Nguyen \& Cassidy, 2018) have shown that in developed economies, cards are a common payment tool, while in emerging or transition economies, the penetration rate of this technology is lower and depends on many elements of local perception. In the choices of consumers may influence other factors, such as demographic variables (gender, age, etc.), socio-economic factors (employment, revenues, life-cycle, etc.), psychographic variables (perception, learning, motivation, etc.) and behavior variables (product choice, brand choice, method of buying choice, etc.) (Keller \& Kotler, 2012). Taking into account all of those variables, it seems necessary to deeply analyze all those influencing factors when we try to evaluate consumer behavior and their choices.

Connolly \& Stavins (2015) showed that payment behavior is strongly correlated with demographic and income attributes over the 2009-2013 period, based on data from the annual Survey of Consumer Payment Choice (SCPC). Recent researches on credit card usage (e.g. Kaynak, Kucukemiroglu, \& Ozmen, 1995; Sharpe, Yao, \& Liao, 2012) found similarities and differences in credit card usage globally. These findings suggest that the usages are influenced by demographic characteristics such as gender, age, education level, income, marital status, culture and attitude towards debt (Abdul-Muhmin \& Umar, 2007; Wickramsinghe \& Gurugamage, 2009).

Besides the importance that all those factors have, for this paper purposes, we have been focused only on the demographic factors, on gender and age of the consumers, to analyze the effect of those two variables on the consumers' choice of buying through cash or using their bank cards. Different kind of literature and studies show that there is a 
positive relationship between age and ownership and between age and usage of bank cards. According to (Zandi, Mansori, \& Hai, 2019) as one grew older, they tend to have a higher status in society with a well-developed career, therefore applicable for more ownership and use of bank cards (debit and/or credit cards). There was also the sign that older generations used to own and use more bank cards to show their privilege over the younger generations (Zandi, Mansori, \& Hai, 2019). Another point highlighted by Vathsala \& Anurudh (2009) was whereby older generation tends to have more expenditure than the younger generation, such as house commitment and more household expenses, therefore, more ownership of especially credit card would help to leverage their expenses, as compared with the younger generation. According to Lim, Ramayah, \& Aizzat, (2002) males tend to own and use bank cards more than females because females used to have weaker financial capabilities as compared with males counterparts. In the other hand, Vathsala \& Anurudh (2009) through their research findings showed that females tend to have more ownership and usage of bank cards, especially credit cards, than males. This was related to the factor that females prefer the rewards and benefits offered by credit card providers whereas males seem to be less attracted by these rewards and benefits, resulting to female having more credit card ownership and usage than male (Vathzala \& Anurudh, 2009).

Based on the reviewed literature we found a gap in the literature regarding the ownership and usability of debit and credit cards in Kosovo focusing on the demographic variables. Therefore this paper aims to investigate the card penetration and usage in Kosovo, based on two demographic variables age and gender of bank clients. Besides we investigate whether commercial banks in Kosovo provide credit cards with preferential rates or incentives for female clients to increase the usage of bank cards by female clients and boost female entrepreneurship.

\section{METHODS}

In order to accomplish the purpose of this paper, we have used the desk research technique by reviewing the existing relevant literature such as research papers, books and reports. For our research purpose, we will use secondary data from Central Bank of Kosovo (CBAK) reports on Use of bank cards in Kosovo for the years 2015 and 2016. Reports are based on data reported by commercial banks in Kosovo. The benefits of secondary data analysis are numerous while carrying out a research such as cost and time, high-quality data, the opportunity for longitudinal analysis, more time for data analysis, reanalysis may offer new interpretations, and the wider obligations of the social researcher (Bryman, 2012).

The comparative methods are widely used in social sciences research. Researchers compare the relative effects of variables across cases; they compare cases directly with one another; and they compare empirical cases with counterfactual cases (Ragin \& Rubinson, 2009). In our research paper, we have used the comparative methods to compare the clients' behavior on the choice of the method to conduct payment and the usage of credit and debit cards in Kosovo banks for two consecutive years (2015 and 2016) based on two demographic factors (variables): gender and age of bank clients.

\section{RESULTS AND DISCUSSION}

In this chapter, the compared results from Central Bank of Kosovo (CBK) reports "Use of bank cards in Kosovo" (CBK, 2016) for the period January - December 2015 and, January - December 2016 (CBK, 2017) of this study are presented. In these two 
reports, the usage of bank cards in Kosovo is presented based on data reported by commercial banks in Kosovo for two consecutive years 2015 and 2016.

According to the data from CBK, (2016) for the year 2015, from the age group 1825 years, 60.8 percent of cardholders are male, while 39.2 percent of them are female. In the age group 26-35 years, 68.7 percent of cards are possessed by the male, while 31.3 percent by the female. For the age group 36-45 years and 46-55 years, the difference is even higher (first group 72.7 percent of cards are owned by male and 27.3 percent by female whereas in second group 73.2 percent by male and 26.8 percent by female) (CBK, 2016).

For the year 2016 based on the CBK, (2017) from the age group 18-25 years, the percentage of the female cardholders is 41.1 percent which is higher compared to the previous year. Similar to this age group, there is also an increase in the percentage of bank card ownership by women for the rest of the age groups of cardholders The same is the case for other age groups where there has been an increase in the percentage of bank card ownership by women.

As can be seen in Figure 1, the vast majority of cards for all age groups for two consecutive years 2015 and 2016 are owned by males. Based on the data presented below we can say that bank cards are owned more by men rather than by female clients.

This gender gap is smaller in younger groups of the customer, but increasing with the increase of age. We can say that the age of female clients is at the inverse proportion with card ownership indicating that the increase of the age of female clients is associated with a decrease in the ownership of the cards by the female. Based on this we can say that older females prefer more traditional inside the bank payment rather than the sophisticated payments with cards. Regarding the variable age for two consecutive years, 2015 and 2016, male and female clients ranging at the age group 25-35 years are the highest-ranked in terms of bank card ownership.This is mainly due to the fact that bank clients from this age group are young and are more likely to be employed/run their own business and have more knowledge to use bank cards.

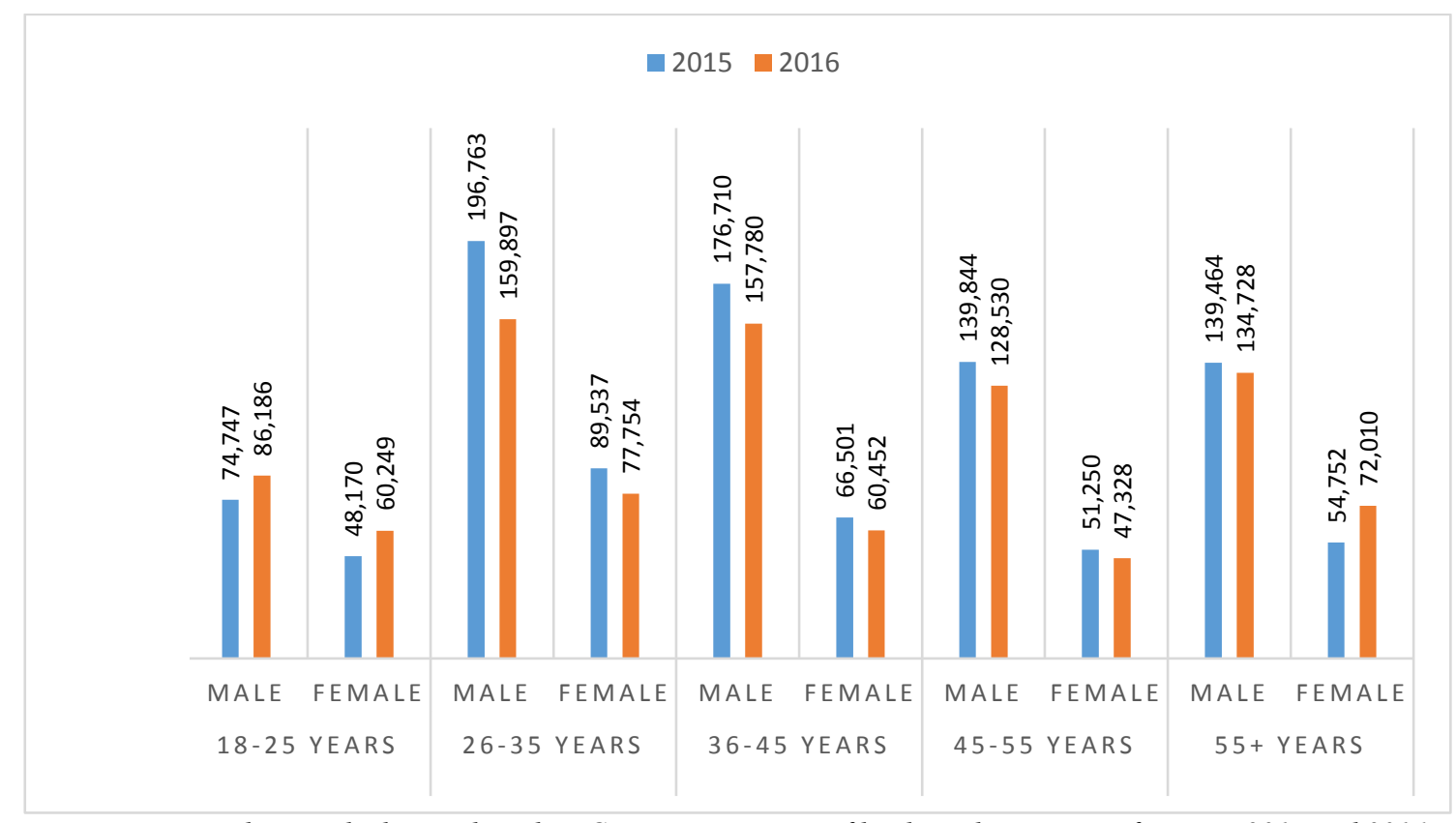

(Source: CBK author's calculations based on CBK report on Use of bank cards in Kosovo for years 2015 and 2016)

Figure 1. Number of cards by age and gender of cardholders in Kosovo, 2015 - 2016 
According to CBK (2016), the age group of 26-35 has performed the largest number of transactions with debit cards, from which $54.5 \%$ of transactions were carried out by males and $45.5 \%$ of females when analyzing the number of card transactions in 2015 (Figure 2). Similarly, in 2016 the age group of 26-35 has performed the largest number of transactions with debit cards, of which $61.1 \%$ of transactions were carried out by males and $38.9 \%$ of females (CBK, 2017). We can suggest that male and female clients of this age group are employed has the highest level of knowledge for the use of electronic payment instruments as well as regular monthly income. In most of the age groups is recorded an increase in the number of payments with debit cards in 2016 expect for the female clients of age group 36-45 years whereas there a slight decrease in the number of payments with debit cards in 2016 when compared to the same the female age group in 2015.

From data in Figure 2 (CBK, 2016; CBK, 2017) it can be seen that clients over 55 years old use less the debit cards for payment, this can come as a result of the lack of knowledge for the use of electronic payments, these categories prefer more traditional banking or for clients over 65 years only a few banks offer cards for pension category clients.

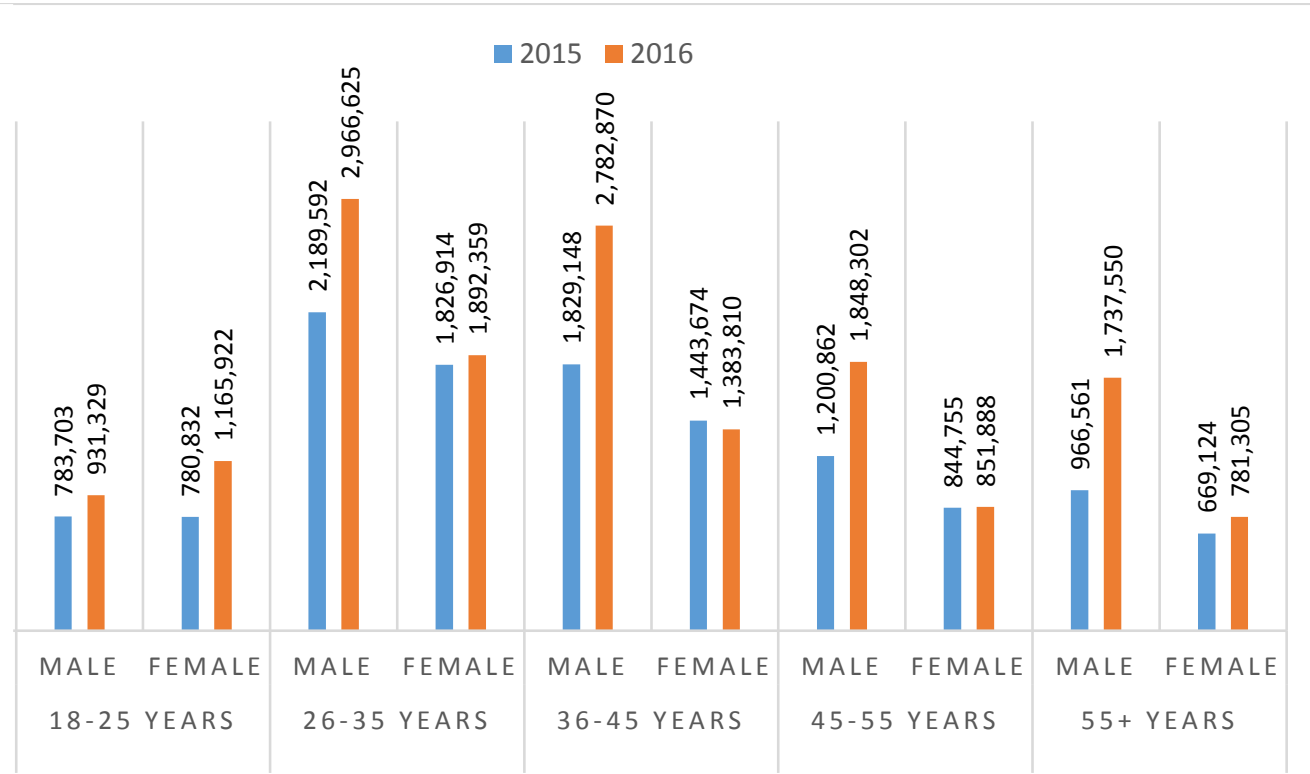

(Source: CBK author's calculations based on CBK report on Use of bank cards in Kosovo for years 2015 and 2016)

Figure 2. Number of payments with debit cards in terminals by age and gender of the cardholders in Kosovo, 2015 - 2016

Female and male bank clients from the age groups 26-35 and 36-45, during 2015 and 2016 have conducted more payments with debit cards compared to other age groups (Figure 3). By comparing the number of payments and the value of payments of these age groups we can conclude that the gap in the number of payments between males and females of these age groups is much smaller than the gap in the value of payments. Whereas 63 percent of the value of debit card transactions was carried out by males within the age group 26-35 years (CBK, 2016), while only 37 percent by females for the year 2015 and 76 percent of the value of debit card transactions were carried out by males within the age group 26-35 years, while only 24 percent by females for the year 2016 (CBK, 2017). 


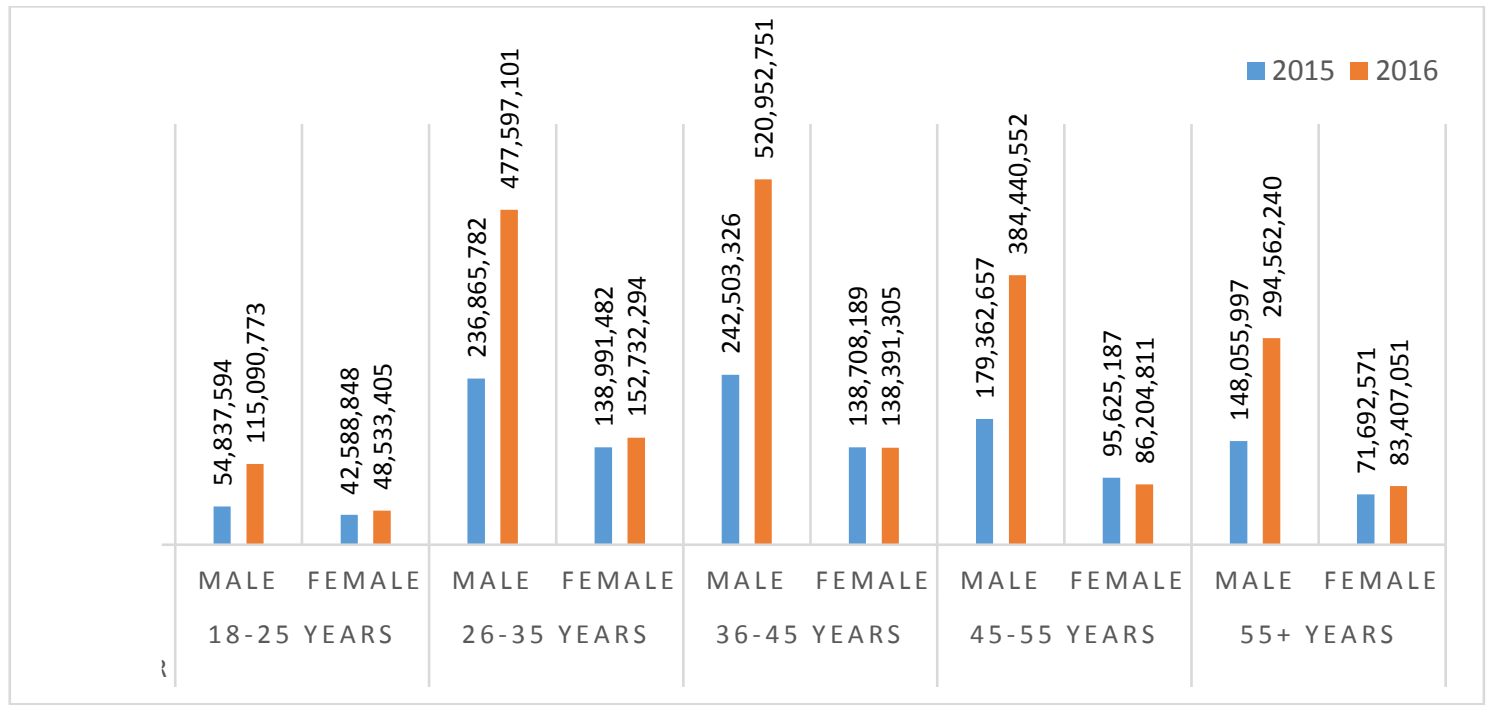

(Source: CBK author's calculations based on CBK report on Use of bank cards in Kosovo for years 2015 and 2016)

Figure 3. The value of payments with debit card in terminals by age and gender of the cardholders in Kosovo, 2015 - 2016

Credit cards are very widely used for payments in ATM and POS terminals and online shopping among both female and male bank clients in Kosovo. From CBK reports (CBK, 2016; CBK,2017) the data are presented in Figure 4, where we can see that people aged 26-35 and those 36-45 conduct the largest number of credit card transactions. Out of the total number of credit card transactions 64.6 percent were carried out by males, while 35.4 percent by females in 2015 and, 71 percent were carried out by males, while 29 percent by females in 2016. The biggest difference lies in the number of transactions by citizens over 55 years, which shows that 74.21 percent of transactions are carried out by males while 25.79 percent are carried out by females for the year 2015 and 80 percent of transactions carried out by males while 20 percent of them carried out by females in 2016. In 2015 the difference is smaller among female and male clients from the group aged 18 -25 years which shows that males of this age group have conducted 55.06 percent of credit card transactions while females 44.94 percent of them (CBK, 2016).

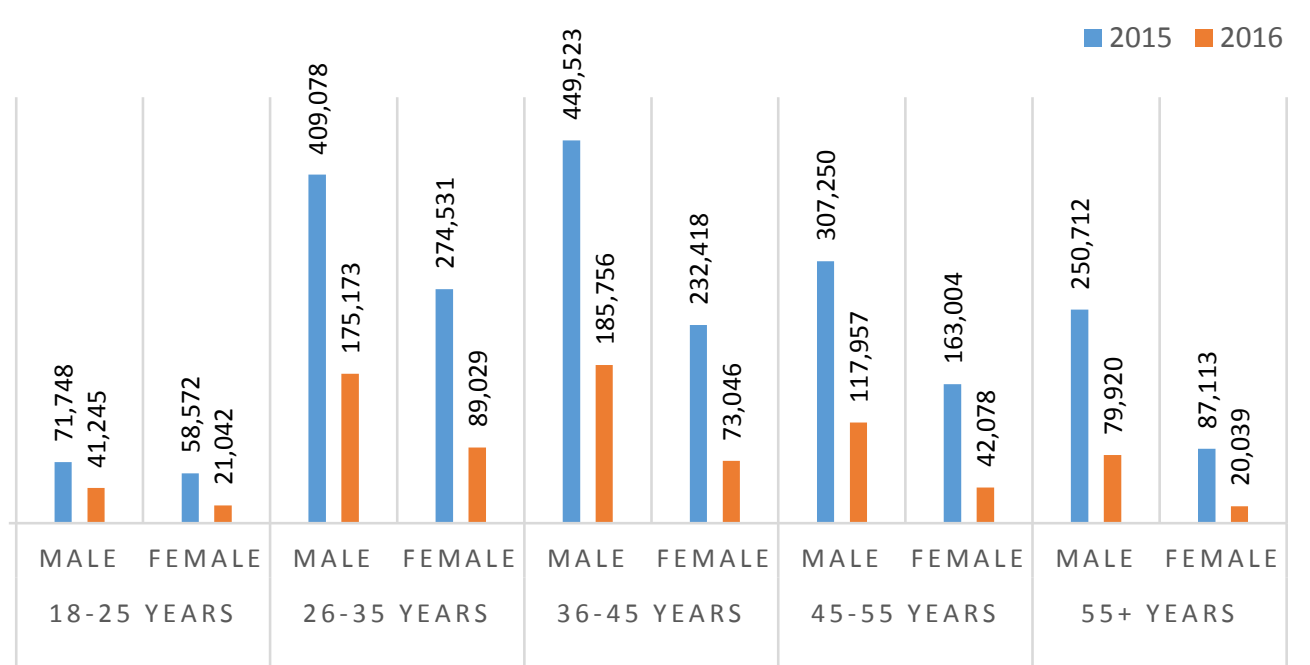

(Source: CBK author's calculations based on CBK report on Use of bank cards in Kosovo for years 2015 and 2016)

Figure 4. Number of payments by credit card on terminals by age and gender of the cardholders in Kosovo, 2015 - 2016 
In Figure 5 is shown the value of credit card transactions carried out in 2015 by the bank clients of Kosovo. As seen from the CBK data 72.77 percent of the value of transactions with credit cards are performed by males, while 27.23 percent are performed by females in 2015 (CBK, 2016), whereas 78 percent of the value of transactions with credit cards is performed by males, and 22 percent are performed by females (CBK, 2017).

The difference among both male and female bank clients from the age group 18-25 years old for the year 2015, is smaller whereas, 61.16 percent of the value of transactions in this age group are performed by males, while 38.84 percent of them performed by females (CBK, 2017).

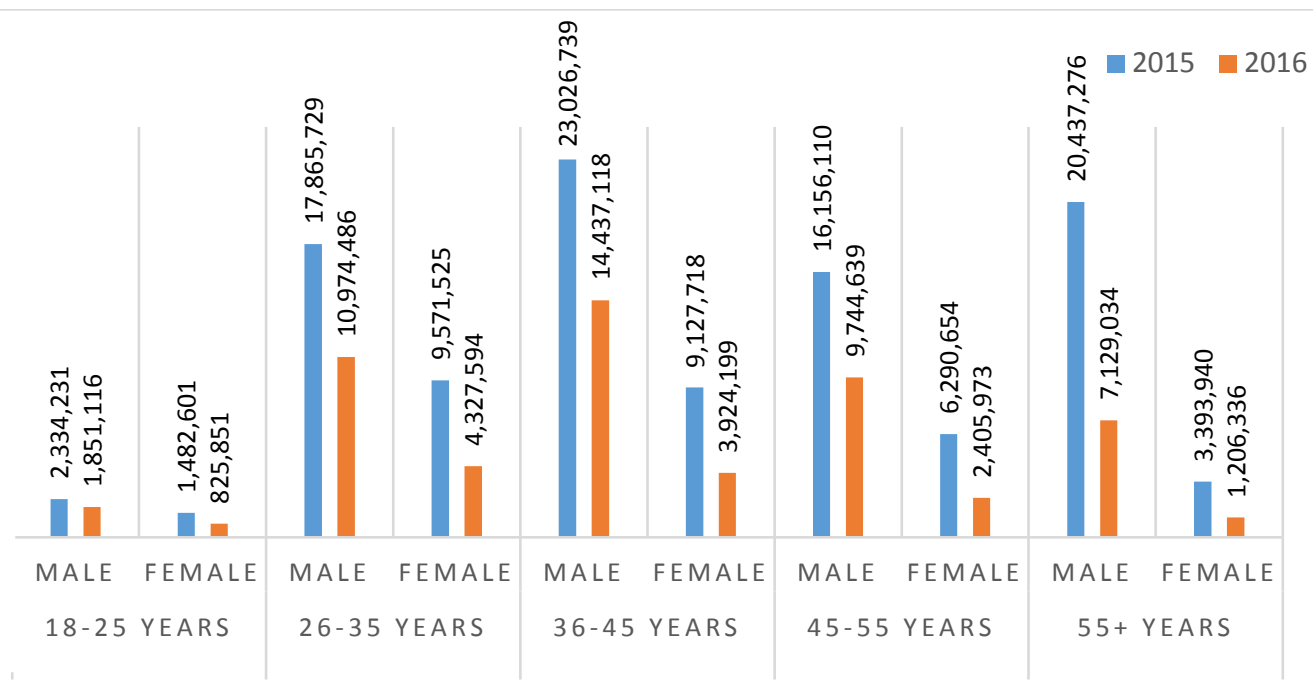

(Source: CBK author's calculations based on CBK report on Use of bank cards in Kosovo for years 2015 and 2016) Figure 5. The value of credit card payment on terminals by age and gender of the cardholders in Kosovo, 2015 - 2016

As can be seen in Figures: 2; 3; 4 and 5, bank clients from the age group 26-35 years use the most debit and credit cards in terms of the number of payments as well as the value of the payments. The smallest gender gap was recorded in 2015 among female and male clients from the group aged $18-25$ years which shows that males of this age group have conducted 55.06 percent of credit card transactions while females 44.94 percent of them (CBK, 2016).

Kosovo is known as one of the countries with a very high acceptance rate of the Internet and, social networks are heavily used. Besides this in Kosovo also have been increased "online" purchases/payments (card payments) through the Internet (CBK, 2016). According to CBK Report in Figure 6 for the years 2015, the largest number of online transactions have been made by males of 26-35 age group with 69.6 percent of the number of transactions compared to females of this age group that have performed 30.4 percent of transactions (CBK, 2016). Whereas for the year 2016 the largest number of online transactions has been made by males of 26-35 age group with 73 per cent of the number of transactions compared to females of this age group that have performed 27 percent of transactions (CBK, 2017).

In general, the gender gap is smaller among the age group 18-25 and 25-35 whereas women are more active and willing to use both bank cards debit and credit for different kinds of payments through ATM, POS and online payments.

The coverage by socio-demographic factors, confirms that the trends of online 
shopping in 2015 show that younger age clients are more familiar with online purchases and consequently payments. If we analyze the coverage by sociodemographic factors, we can confirm that the trends of online shopping in 2015 and 2016 shows that younger age clients have Computer literacy, ability to surf in worldwide webs (www) are more familiar with online purchases and consequently payments. Therefore, most of the online transactions/payments with cards are done from clients of the age group 26-35 since clients of this age group are young and are more likely to have a job/salary or are running their own business. Regarding the online payment/purchase with bank cards, we can say that the gender gap is smaller among age groups 18-25 and 26-35.

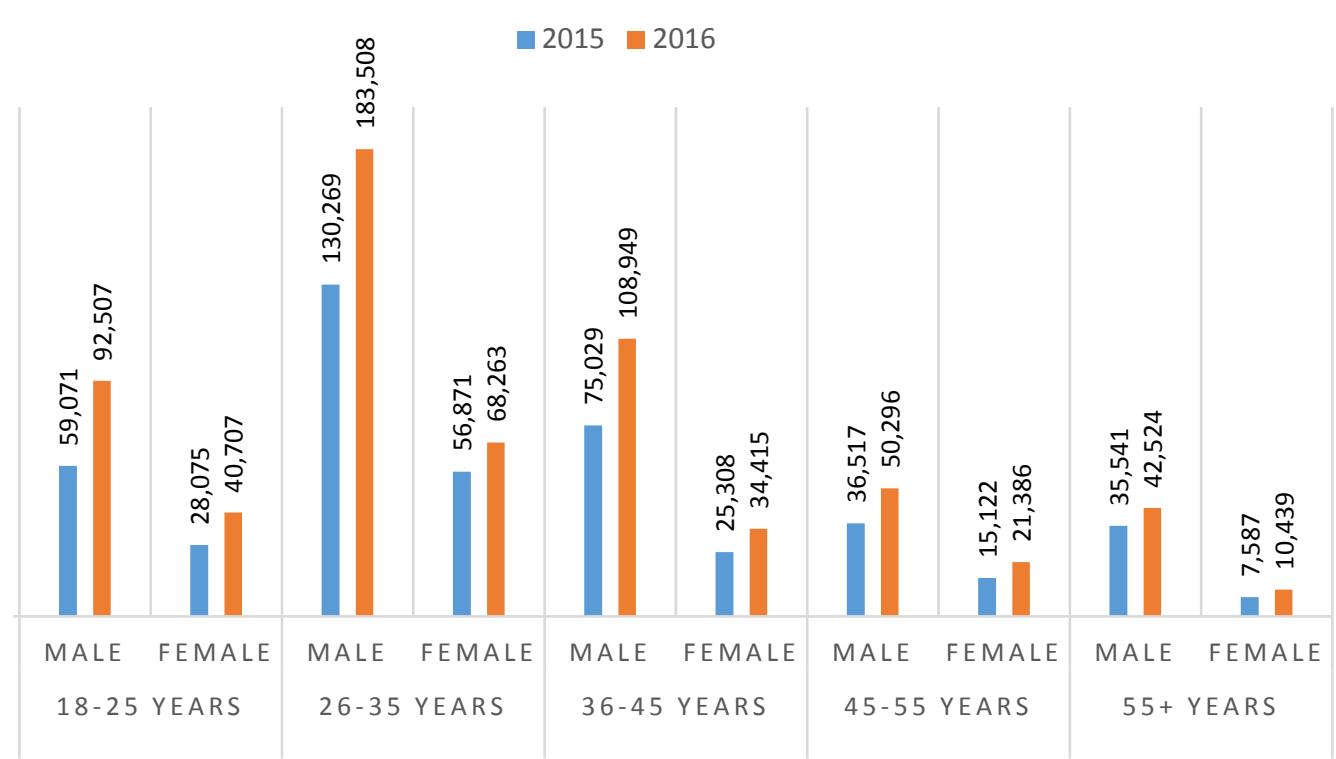

(Source: CBK author's calculations based on CBK report on Use of bank cards in Kosovo for years 2015 and 2016)

Figure 1. Percentage of online payments by age and gender of the cardholders in Kosovo, 2015 $-2016$

According to data in Figure 7, whereas is shown the value of "online" payments by card, women lag on "online" payments compared to their male counterparts. From all age groups, males are the ones who perform more "online" payments for both years (2015 and 2016). Whereas, the value of "online" transactions by clients aged 26-35 and those aged 36-45 have the highest participation in the total value of "online" payments for two consecutive years 2015 and 2016. When providing more detailed information for the year 2015 in the age group 26-35, 74.5 percent of "online" payments are committed by males, while 25.5 percent by females (CBK, 2016) and we have the same situation in 2016 as well, whereas 73 percent of "the online" payments are committed by males, while 27 percent by females (CBK, 2017). This gender gap is higher in the age group 36-45, whereas from the total value of "online" card payments, 80.4 percent of them is performed by males and only 19.6 percent of them by female bank clients (CBK, 2016).

Whereas for other age groups this gap is higher and the highest gap was recorded for the year 2016 in the age group +55 , whereas from the total value of "online" card payments, 88 percent of them is performed by males while only 12 percent of them by females (CBK, 2017). Our findings are in line with Connolly \& Stavins (2015) indicating that card usage and payment behavior are strongly correlated with demographic factors and income attributes. 


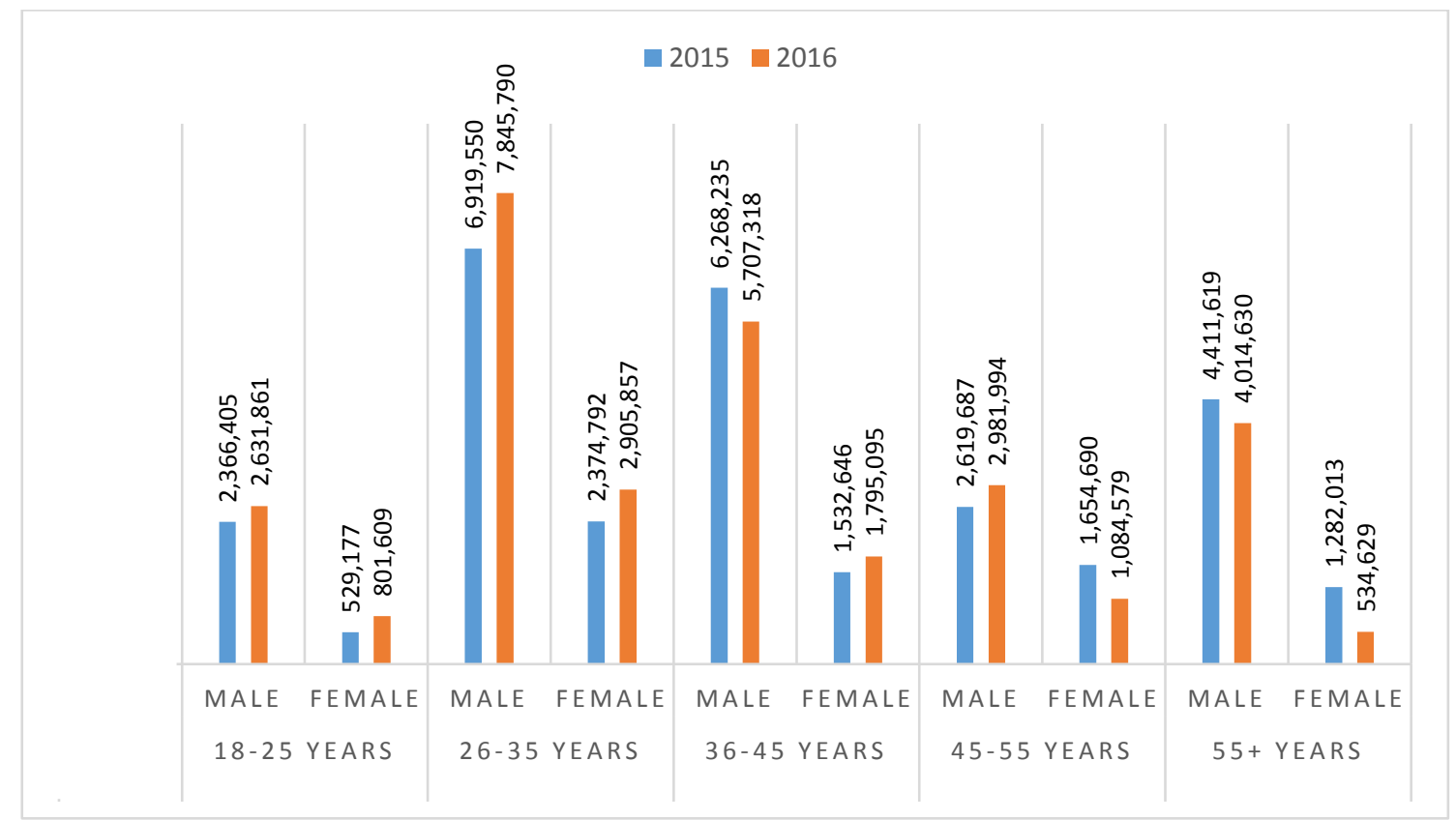

(Source: CBK author's calculations based on CBK report on Use of bank cards in Kosovo for years 2015 and 2016)

Figure 2. The value of online payments with cards via the internet by age and gender of the cardholders in Kosovo, 2015 - 2016

Regarding the variable age, our research indicates that the highest acceptance and usage/payment/purchase rate for debit and credit cards, in general, is among the bank clients that are 35 years or younger (age groups 18-25 and 26-35) this and mainly due to their preference and knowledge to use the card and online payments. These results are not in line with Zandi, Mansori, \& Hai (2019) indicating that as one grew older, they tend to have a higher status in society with a well-developed career, therefore applicable for more ownership and use of bank cards (debit and/or credit cards) and that older generation used to own and use more bank cards to show their privilege over the younger generation. Our results are not in line also with Vathsala \& Anurudh (2009) that point out that the older generation tends to have more expenditure than the younger generation, such as house commitment and more household expenses, therefore, more ownership of especially credit card would help to leverage their expenses. Regarding the variable gender, our findings are in line with Lim, Ramayah, \& Aizzat, (2002) indicating that males tend to own and use bank cards more than females because females used to have weaker financial capabilities. In contrary to our results Vathsala \& Anurudh (2009) showed that females tend to have more ownership and usage of bank cards, especially credit cards, than male since females prefer the rewards and benefits offered by credit card providers whereas males seem to be less attracted by these rewards and benefits.

The following question arises: What have done banks to attract these two categories female and older people toward higher ownership and usage of bank cards? Based on our desk research we found that banks are having some promotional offers such as one of the foreign banks operating in Kosovo is offering to female clients regular credit cards plus an additional credit card called "SheCard" thus enabling two parallel credit card limits only for female clients, as well as additional promotional benefits (TEB, 2020). Another bank offers credit bonus cards for the female with a more beautiful pink and figure design but with same conditions as for male bonus credit cards expect for some holidays such as women's international day provides promotional offers such as 10 percent discount to perfumery and cosmetics merchants (Raiffeisen Bank, 2020). Regarding the variable age 
in the particular age group 55+, the offers from banks to enhance the ownership and usage of this clients the offers from banks are scarce. Only a few banks offer debit bank cards for pension accounts whereas in most of the banks the pension payments are done inside the bank through traditional banking by waiting in long lines in front of the banking counter.

\section{CONCLUSIONS AND RECOMMENDATIONS}

\section{Conclusions}

According to CBK (2017) the citizens of Kosovo are using mostly debit cards, which are linked to their current or payroll account and allow them to carry out transactions up to the amount of available funds, and credit cards that allow transactions according to credit limits approved by the card-issuing bank. The majority of cards issued and used in Kosovo are VISA and MASTERCARD brands. Based on the obtained results by comparing the reports of CBK for two consecutive years 2015 and 2016 regarding the use of cards from bank clients in Kosovo banks we can conclude that bank cards are used widely. The usage of bank cards in this paper is analyzed by focusing on two demographic factors, on gender and age of the consumers, aiming to analyze the effect of those two variables on the consumers' choice of buying through cash or using their bank cards. Initially, we have investigated the ownership of the bank cards focusing on the gender and age of clients.

Based on our research results we can conclude that demographic factors have an impact on the ownership and usage of debit and credit cards for different kinds of payments. Debit and credit bank cards in Kosovo are generally used more by males rather than by female clients. The gender gap is smaller in terms of card usage and online card payments in the category of age groups 18-25 and 26-35. Also regarding the variable age, we can conclude that usage of both debit and credit for ATM transactions, POS payments and online payments, in general, are higher for 35 years and younger male and female bank clients, mainly due to their preference and knowledge to use the card and online payment.

Banks in Kosovo are having some promotional offers for female clients by offering an additional credit card thus enabling two parallel credit card limits, some of the banks offer beautifully designed and colorful credit cards and some incentives are also offered such as a discount for women's international day and other holidays mainly with perfumery and cosmetics merchants. None of the banks in Kosovo does offer business credit cards with preferential rates or incentives for female entrepreneurs. Whereas for the oldest clients only a few banks offer debit bank cards for pension accounts.

\section{Recommendations}

We suggest that banks should do more to enhance the ownership and usage of debit and credit cards by females and elderly clients. In particular, we recommend banks to offer credit and bonus cards with preferential rates to female entrepreneurs considering the very small number of female entrepreneurs and to boost female entrepreneurship in Kosovo. We believe that the Government can facilitate and support banks with such initiatives having into consideration the high unemployment rate of females in Kosovo and the crucial importance of SMEs as the generator of employment worldwide.

In addition, we recommend banks in Kosovo to offer bank cards with numerous promotional offers for mothers with small children in terms of special agreements with Baby shops - merchant partners while paying at the POS. Banks need to address such 
initiatives to the Government by asking to be supported and facilitated by Government considering that these initiatives will have an impact on increasing female employment, reducing unemployment and increasing the countries birth rate or natality.

\section{REFERENCES}

Abdul-Muhmin, A. G., \& Umar, Y. A. (2007). Credit Card Ownership and Usage Behaviour in Saudi Arabia: The Impact of Demographics and Attitudes toward Dept. Journal of Financial Services Marketing, 12(3), 219 - 234

Avdullahi, A. (2014). Acceptance of E-Banking Services from Small and Medium Enterprises. Horizons International Scientific Journal Economic, 12, 51-62

Avdullahi, A., \& Fejza, V. (2015). Efficiency Improvement and Quality Initiatives Application in Financial Institutions. Iliria International Review, 5(1), 133-147.

Bryman, A. (2012). Social Research Methods (4 ed.). New York, United States of America: Oxford University Press Inc.

CBK. (2016). Use of bank cards in Kosovo. CBAK. Prishtina: Central Bank of Kosovo CBK. Retrieved from https://bqk-kos.org/repository/docs/2015/ Use\% 20of\% 20bank\% 20cards\%20in\%20Kosovo.pdf

CBK. (2017). Use of bank cards in Kosovo. CBAK. Prishtina: Central Bank of Kosovo. Retrieved from https://bqk-kos.org/repository/docs/SistemiIPagesave/ Use\% 20of\% 20bank\%20cards\%20in\%20Kosovo.pdf

Chaker, M. N. (2015). Consumers's perceptions of banks country of origin in the UAE. Eurasian Journal of Economics and Finance, 3(3), 25-34.

Connolly, S., \& Stavins, J. (2015). Payment Instrument Adoption and Use in the United States, 2009 - 2013, by Consumers' Demographic Characteristics. Boston: Federal Reserve Bank of Boston Research Data Report .

Dospinescu, O., Anastasiei, B., \& Dospinescu, N. (2019). Key Factors Determaning the Ecpeted Benefit of Customrs When Using Bank Cards: An Analysis on Millennials and Generation Z in Romania. Symmetry, 11(12), 2-20.

Eyubolu, K. \& Sevim, U. (2017). Determinants of Contactless Credit Cards Acceptance in Turkey. International Journal of Management, Economics and Business, 13(2), 331-346.

Fejza, V., Bajrami, H., \& Livoreka, R. (2018). Consumer Behavior in Commercial Banks of Kosovo. International Journal of Business and Management, VI(2), 17-35.

H. Lee, M., \& John W, S. (1969). Social Class and Commercial Bank Credit Card Usage. Journal of Marketing, 33(1), 71-78. doi:10.1177/002224296903300112

Kaynak, E., Kucukemiroglu, O., \& Ozmen, A. (1995). Correlates of Credit Card acceptance in advanced developing Middle Eastern Country. Journal of Sevices Markeing, 9(40), 52 - 63

Keller, K., \& Kotler, P. (2012). Marketing Management. 14th Edition. New Jersey: Prentice Hall.

Lim, H. C., Ramayah, N. N., \& Aizzat, M. N. (2002). Cardholders' attitude and bank credit card usage in Malaysia: An exploratory study. Asian Academy of Management Journal, 7(1), 122-134.

Mann, J. R. (2007). Charging Ahead: The Growth and Regulation of Payment Card Markets. New York, United States of America: Cambridge University Press.

Nguyen, O. D., \& Cassidy, J. F. (2018). Consumer Intention and Credit Card Adoption in Vietnam. Asia Pacific Journal of Market Logistics, 30(4), 779-796. 
Ragin, C. C., \& Rubinson, C. (2009). The Distinctiveness of Comparative Research. In Landman, T \& Robinson, N. (Eds.), The Sage Handbook of Comparative Politics, 13 - 34. Sage Publishing

Raiffeisen Bank. (2020). Raiffeisen Bank Kosovo. Retrieved from https://www.raiffeisenkosovo.com/eng/individuals/products-and-services/cards/bonus-cards/

Sharpe, D. L., Yao, R., \& Liao, L. (2012). Correlates of Credit Card Adoption in Urban China. Journal of Family and Economic Issues, 33, 156 - 166

TEB, B. (2020). SheCard - The unique card for her Retrieved from https://www.tebkos.com/en/index.php/per-individe/kartelat-individe/shecard-visa/

Vathzala, W., \& Anurudh, G. (2009). Consumer Credit Card Ownership and Usage Practices: Empirical Evidence from Sri Lanka. International Journal of Consumer Studies, 33(4), 436-447.

Wang, Y. (2008). Determinants Affecting Consumer Adoption of Contactless Credit Card: An Empirical Study. Cyber Psychology Behavior, 11(6), 687-689.

Wickramsinghe, V., \& Gurugamage, A. (2009). Consumer Credit Card Ownership and Usage Practices: Empirical Evidence from Sri Lanka . International Journal of Consumer Studies, 33(4), 436 - 447.

Zandi, G., Mansori, S., \& Hai, O. B. (2019). The Effect of Demographic Variables and Ownership on Credit Card Market in Malaysia. International Journal of Financial Research, 10(5), 359-369. 